\title{
Towards eco-social housing in Vietnam: challenges and opportunities
}

\author{
Van Thuong Le ${ }^{1}$, Tuan $\operatorname{Tran}^{1}$, and Truc Truong ${ }^{1, *}$ \\ ${ }^{1}$ Ho Chi Minh City University of Architecture, 196 Pasteur, Ho Chi Minh, Vietnam
}

\begin{abstract}
Since Doi Moi (Reform) policy in 1986, Vietnam has experienced rapid urbanization and economic growth. Urbanization has resulted in increasingly high housing demand in the urban areas but this has largely unmet, especially housing for low-income people. Development of social housing for low-income and under-privileged people in cities has been seen as an urgent and important task of the government to pursue stable social and economic development. Low-income people are most vulnerable to environmental impacts and in need of energy-efficient houses to reduce their cost of living. Eco-social housing is seen as a solution to protect the natural environment as well as to boost local economy, improve living conditions particularly for low income people. Through preliminary assessments of three social buildings at three distinct regions of Vietnam, this paper found that despite many challenges, eco-social housing is a solution to Vietnam's needs in providing houses with adequate living conditions to low-income people while protecting the environment and achieving sustainable eco-social development in the long run.
\end{abstract}

\section{Introduction}

Over the past thirty years of the Doi Moi (Reform) policy, Vietnam has experienced a rapid growth and became an example of remarkable success after gradually giving up the centrally planned economy and integrating into the global market economy. Since then, its economic development resulted in rapid urbanization since people flocking to cities for job and other opportunities. Urbanization has helped to cut down the unemployment rate, shifted the employment pattern from informal into formal and high productivity jobs, thus supported and sustained the economic growth. The average growth rate of the urban population in Vietnam is 3.5 percent per year since 2000[1]. By 2020, nearly half of Vietnamese people will live in urban areas (Table 1).

Population and urbanization growth has resulted in high demand of housing in cities, especially in large cities such as Hanoi and Ho Chi Minh City (HCMC). These are the two largest metropolitan areas, accounting for 50 percent of urban land in the country and in need of 244,000additional units each year [1]. A study by JLL Research in 2016 [2] indicates that nearly 94,000 completed apartments and 80,000 completed apartments are recently supplied for Hanoi and HCMC markets in 2016, respectively.

\footnotetext{
*Corresponding author: tuan.tranhuuanh@uah.edu.vn
} 
Table 1. Number of cities and urban population rate (Source: Decision No. 445/2009/QD-TTg by the Prime Minister approving the Orientation for Vietnam Urban Development Master Plan until 2025, with vision until 2050).

\begin{tabular}{|c|c|c|c|c|c|}
\hline Year & $\mathbf{1 9 9 9}$ & $\mathbf{2 0 1 1}$ & $\mathbf{1 0 / 2 0 1 2}$ & $\mathbf{2 0 1 5}$ & $\mathbf{2 0 2 0}$ \\
\hline Number of cities & 629 & - & 762 & 870 & 940 \\
\hline Urban population rate & $20.7 \%$ & $31.5 \%$ & $32 \%$ & $38 \%$ & $45 \%$ \\
\hline
\end{tabular}

Therefore, the total supply is only around 174,000 units which is about a half of the housing demand.

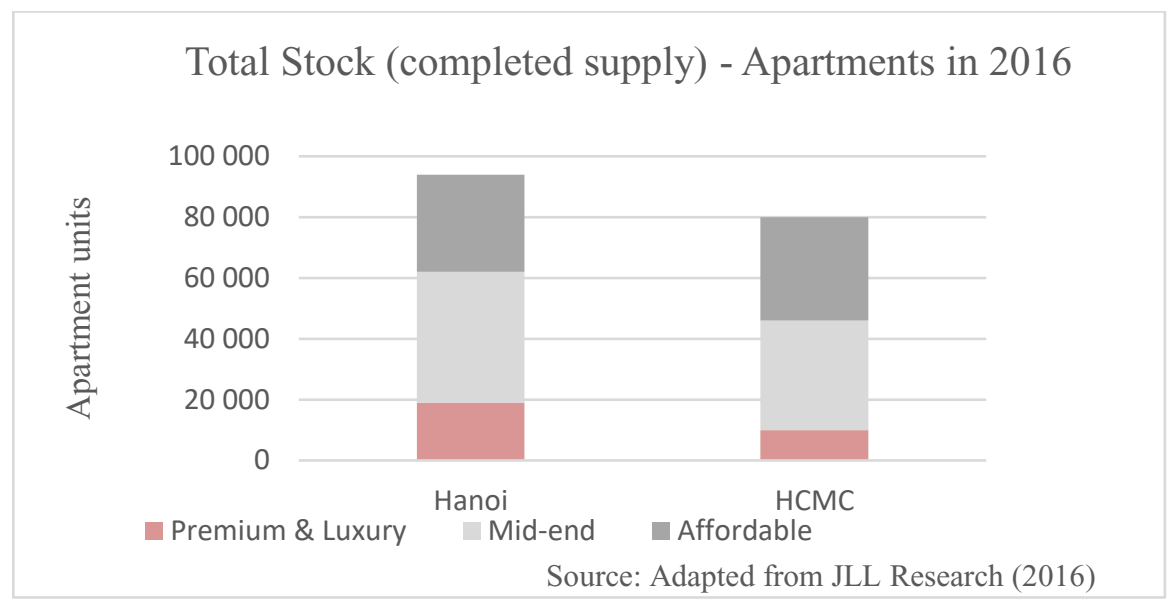

Fig. 1. Total completed apartment supply in Hanoi and HCMC in 2016.

In spite of the big gap between demand and supply of housing, there are often high property inventory in the real estate market since the average price of apartments are beyond the financial affordability of an average income household. An affordability analysis by Work Bank in 2015 [1] based on income urban groups indicates that only top income quintile can afford commercial units With an average monthly income of US\$527, a house hold can afford a house at the total price less than US\$14,000 (with 70\% bank loan of 20 years at the average interest rate of $10 \%$ per annum). Even with affordable apartments at US\$750 per sqm, without government subsidy, the average selling price of a standard 25 square meter housing unit will cost around US\$18,750. Thus, owning a house in cities is too difficult to reach for many low income people.

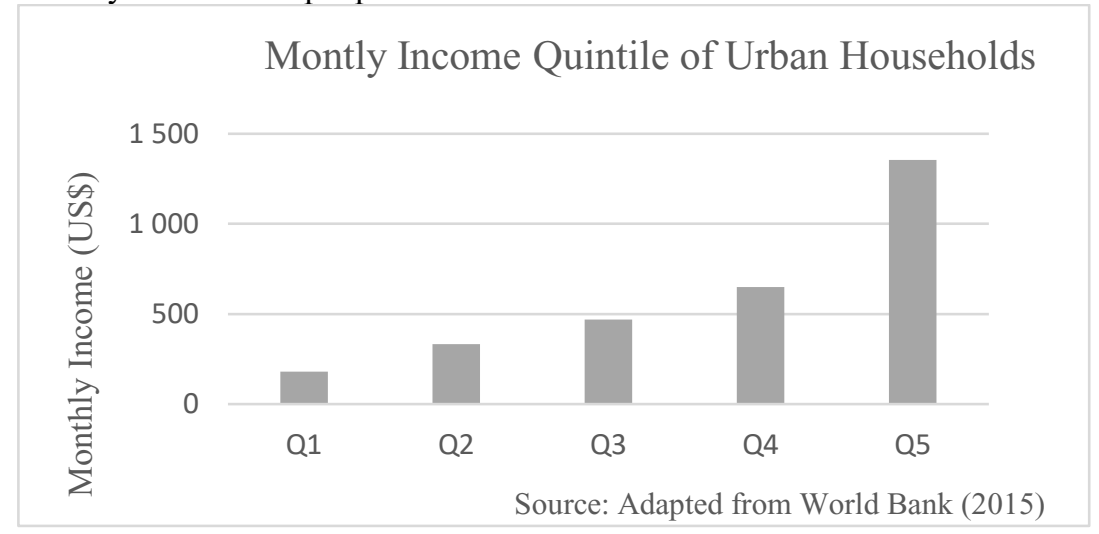

Fig. 2. Affordability based on Income Quintiles of urban Households (in USD). 


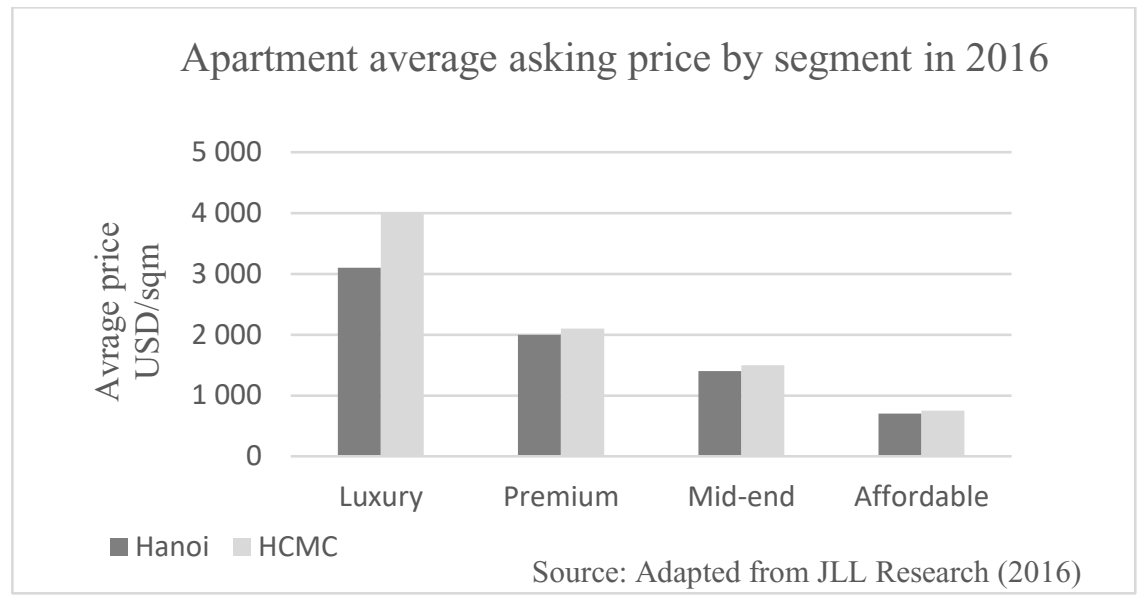

Fig. 3. The apartment average asking price by segment in 2016 .

Commercial and residential buildings world wide account for 20.1 percent of total energy [3]. In Vietnam, the number (Including offices, houses, retails, banks, and hotels) is 40percent, in terms of electricity consumption [4]. Rapid urbanization and economy growth in emerging market countries like Vietnam are reasons causing an increase in energy consumption. By 2015, total electricity consumption of Vietnam in 2015 is more than 143 Bwh (billion watt hour $\left.\left(10^{9} \mathrm{wh}\right)\right)$ which is twice times of that in 2010 [4].

Energy consumed by buildings through construction activities and building operations are mainly generated from burning fossil oil, natural gas, and coal. This is the main reason of excessive carbon dioxide and other greenhouse gas emissions into environment [3], causing global warming, resulting in sea level rise which puts millions of people worldwide in danger (Wang and Chameides, 2005). As a country with long coastline with many lowland areas prone to floods and storms, Vietnam is facing high potential impacts from climate change, affecting its economy and human loss [5].

The term eco-social housing generally refers to affordable housing which describes the concept of green buildings which are affordable to a certain target market or community [6]. Eco-affordable housing comprises of two components: (1) ecological responsibility and (2) affordability [6]. Ecological responsibility refers to green building guidelines, or other ecological principles defined by the community. Affordability refers to financial affordability to a target of market which mostly address to low-income people. For that reason, the term eco-social housing can be used interchangeably with the termeco-affordable housing within the context of this study.

Eco-building trends become popular worldwide, however, that is not the case for Vietnam, especially in social housing. Can ecological design features and social houses get along to wards eco-affordable or eco-social housing for low-income people in Vietnam? Is there any green or ecological design already applied in existing practices of design and construction of social buildings in Vietnam? This paper aims to identify and analyze challenges and opportunities of eco-social housing through conducting preliminary assessment of three social buildings at three different large cities representing distinct climates of Vietnam: Hanoi, Nha Trang and HCMC.

\section{An overview of eco-social housing context of Vietnam}

\subsection{Social housing in Vietnam}


In many countries, affordable housing and social housing are used as housing programs in tackling housing inequality to "ensure adequate housing and living conditions for all" [7]. In Canada, for example, the terms social housing refers to rental housing subsidized by government while affordable housing is often used interchangeably with the term social housing but in a broader term, including housing provided by the private, public and nonprofit sector as well as all forms of housing tenure[8].

In Vietnam, between 1960s and 1970s, there was no clear definition for the concept of social housing but the government is mainly in charge of issuance of subsidy housing policies and delivery of government-owned rental housing to civil servants. After Doi Moi in 1986, this program was gradually replaced by more open policies that starting recognition the right of private property ownership and exchange rights, encouraging participation from private sectors in providing housing or self-built housing. However, between 1980s and 1990s, the government still played a dominant role in providing housing to its civil servants [9].

The term "nha o uu dai", a concept which is close to "social housing", is first mentioned in the government Decree 71/2001/NĐ-CP, referring to sale or rental housing models (normally apartment types) to certain people such as civil servants, workers and students. The Decision No. 76/2004/QĐ-TTg also introduced "quy nha o" which is close to "social housing fund", requiring developers to leave a proportion of their land or apartments as "a fund" for those people. Not until 2005, the concept of social housing was firstly defined in the Housing Law 2005 (56/2005/QH11) that social houses are sale or rental houses built by state or private sectors to the people specified in the Law. The current Housing Law 2014 (65/2014/QH13) only expands the beneficiaries of the social housing policy [9].

More incentives in social housing policies were introduced, including land acquisition support, land use tax incentive, preferential rate loan, credit incentive and so on. By end of 2015, 135 social housing projects funded from the 30 trillion VND loan housing stimulus package (so-called 30 trillion VND loan package) were completed, including 51 projects for low income people and 84 projects for industrial workers as well as 85 projects providing accommodations up to 220,000 students [10]. Despite many projects were funded from the package, providing stable housing and at standard living condition to millions of people, the social housing loan program is facing a lot of barriers, affecting its continuation.

- Limitations from the instability of the government support on social housing

There is the instability from governmental supports on social housing program, which affects the social housing market including both investors and targeted people. For example, the 30 trillion VND loan package for quantified people allowing them to buy social house units at a lower interest rate was suspended despite the total loan disbursement only reached at around $10 \%$ of the designated fund [11]. This means some people whose loans were not disbursed on the right time, due to late construction progress or complicated process, had to pay at market interest rates. Investors are also affected by the interruption as their completed social housing projects have no new customer and many plans of their upcoming social projects have being affected.

- Lacking of interest of social housing development from private sectors

Social housing market also is still not attractive to commercial developers for many reasons such as so complicated and time-consuming procedures at all phases of a social housing project. The fixed $10 \%$ margin profit for social housing projects is also another restraint. In addition, there is no clear government directive on the continuation of the 30 trillion VND loan package affecting private sectors' confidence in government's commitment on the housing program.

- Lacking of land bank for social housing projects.

A lacking of land for social housing projects is also a barrier to the deployment of social housing projects across the country. Although by law, any commercial housing project with a land larger than 10 ha has to set aside $20 \%$ of its land for social housing fund. Many 
commercial developers however have been reluctant to adopt this requirement or they do not strictly adhere the law. Some of them might leave unfavorable lands or lands without going through compensation and clearance to social housing fund, causing lot of difficulties to development of social housing investment projects.

- Quality of current social housing houses.

Some social housing projects which have recently been completed and but soon found many problems such as quick deterioration, failure causing residents difficulties and affecting their daily lives. These problems are often explained by the fact that the low margin profit for the social housing projects resulting in lower quality materials and equipment being used for social projects. Social houses therefore have bad reputation for the low quality and lack of essential amenities.

\subsection{Current state conditions of eco-social housing in Vietnam}

Abnormal weather and harsh climate events have increased in recent years, resulting in the gradual change in public awareness on environmental protection. A survey of public awareness on this topic found that many Vietnamese people are increasingly interested in environmental issues, especially air pollution and waste problems. However, the barrier is that it comes to the cost issue when purchasing green or eco-products in Vietnam is still limited [12].

Table 2. Rank of environmental issues by the level of concern (Source: adopted from Hoang Van Hai and Nguyen Phuong Mai (2012) [12]).

\begin{tabular}{|c|c|c|}
\hline Rank & Environmental issues & $\begin{array}{c}\text { Percentages of "very interested" } \\
\text { respondents (\%) }\end{array}$ \\
\hline 1 & Air pollution & 52.1 \\
\hline 2 & Waste problem & 50.5 \\
\hline 3 & River problem & 35.9 \\
\hline 4 & Forest destruction & 37.1 \\
\hline 5 & Ecosystem destruction & 32.7 \\
\hline 6 & Energy/resource depletion & 32.1 \\
\hline 7 & Marine pollution & 27.6 \\
\hline 8 & Global warming & 26.3 \\
\hline 9 & Ozone depletion & 24.8 \\
\hline 10 & Soil pollution & 25.7 \\
\hline 11 & Desertification & 15.2 \\
\hline
\end{tabular}

Green building has increasingly gained a lot interest in Vietnam recently, especially when many international green building certification programs were introduced such as LEED (Leadership in Energy and Environmental Design) of the U.S., Green Mark of Singapore and EDGE (Excellent in Design For Great Efficiencies) of IFC (International Finance Corporation of World Bank Group). In term of local organizations, Vietnam Green Building Council (VGBC) - a member of World Green Building Council Network launched the first local green building certification program for Vietnam in 2007 [13]. Despite of a lot of effort and support from government, the number of buildings successfully implemented the green building certification system and received the final certification is limited (Table 3). It should be noted that there is no social housing project adopting green building certification system at this time. Cost is a big barrier for any building adopting green building certification system and with social-housing projects it is not exclusive. There is a common notion that the adoption of green practices for buildings will increase cost. The cost increase comes from smarter systems or equipment, high efficiency building systems and so on [14]. 
Table 3. A summary of certified green buildings in Vietnam (Data obtained from organizations' website published by $1 / 10 / 2016)$.

\begin{tabular}{|c|c|c|c|}
\hline $\begin{array}{c}\text { Green building } \\
\text { certification system }\end{array}$ & Registered & Final certified & $\begin{array}{c}\text { Total } \\
\text { buildings }\end{array}$ \\
\hline LEED & 23 & 16 & 39 \\
\hline EDGE & 5 & 1 & 6 \\
\hline LOTUS & 14 & 6 & 20 \\
\hline
\end{tabular}

For eco-social housing in Vietnam, the budget is tighter than that for other commercial housing. Other barriers are from the emerging green construction industry in Vietnam lacking of designers, contractors having adequate resources, knowledge and skills as well as limited availability of certified green material, equipment in the local market.

\section{Methods}

To address the research questions, an assessment of three recently-constructed social apartments to identify whether any green or ecological responsibility incorporated in social buildings in practice. The three buildings are selected from three different cities whose climates represent for distance climates of Vietnam.

This study adopts the notion of the eco-affordable housing ecologically responsible and financially affordable to low-income people [6]. Ecological responsibility refers to green building guidelines, or other ecological principles. To further elaborate the term ecological principle, this study adopts the concept of ecological design from Samy and Mohamed (2015) [15], to investigate five ecological design features as follows:

- Durable design: design that allows a building to be last long and weather resistance, having low level of maintenance.

- Climate considerations: aspects regarding passive designs based on local climate conditions.

- Human health considerations: thermal comfort, indoor air quality and so on.

- Environmental considerations: resource efficiency approaches to reduce impact to the environment.

- Eco-materials: materials with low embodied energy, low on-going maintenance level and potential recyclability.

\section{Results}

Three buildings located at three different cities with distinct climates were assessed under five ecological design features: (1) durable design, (2) climate considerations, (3) human health considerations, (4) environmental considerations, and (5) eco-materials. The following sections are going to summarize these buildings' assessments, starting with the building description, local climate characteristics and ecological design features.

\subsection{Building $A$}

- Building description:

The social apartment Dang Xa II, in Da Xa, Gia Lam Hanoi was developed by Viglacera Company. The project consists of four midrise blocks (V1, V2, V3 and D10) up to six stories and is located on the land area of 14,000sqm. These blocks are characterized by leaving the first floor as unoccupied space for parking, utilities and public space for community. All 
apartment units are from the second floor to the sixth floor, with the units' floor area varying from 45 sqm.to $75 \mathrm{sqm}$.

- Local climate characteristics:

Hanoi climate is characterized as a warm humid subtropical climate with high precipitation up to 1,680 millimeters per year, the high precipitation period from May to September. Hanoi is one of a few cites in Vietnam having four distinct seasons. Summer (May until August) is hot and humid with heavy rainfall. Fall (September to October) and spring (February to April) is the most pleasant time in Hanoi with a decrease in temperature and precipitation. Winter, from November to January, is dry and cool. The average annual temperature is $23.6^{\circ} \mathrm{C}$ with a mean relative humidity of $79 \%$.

Table 4. Building A.

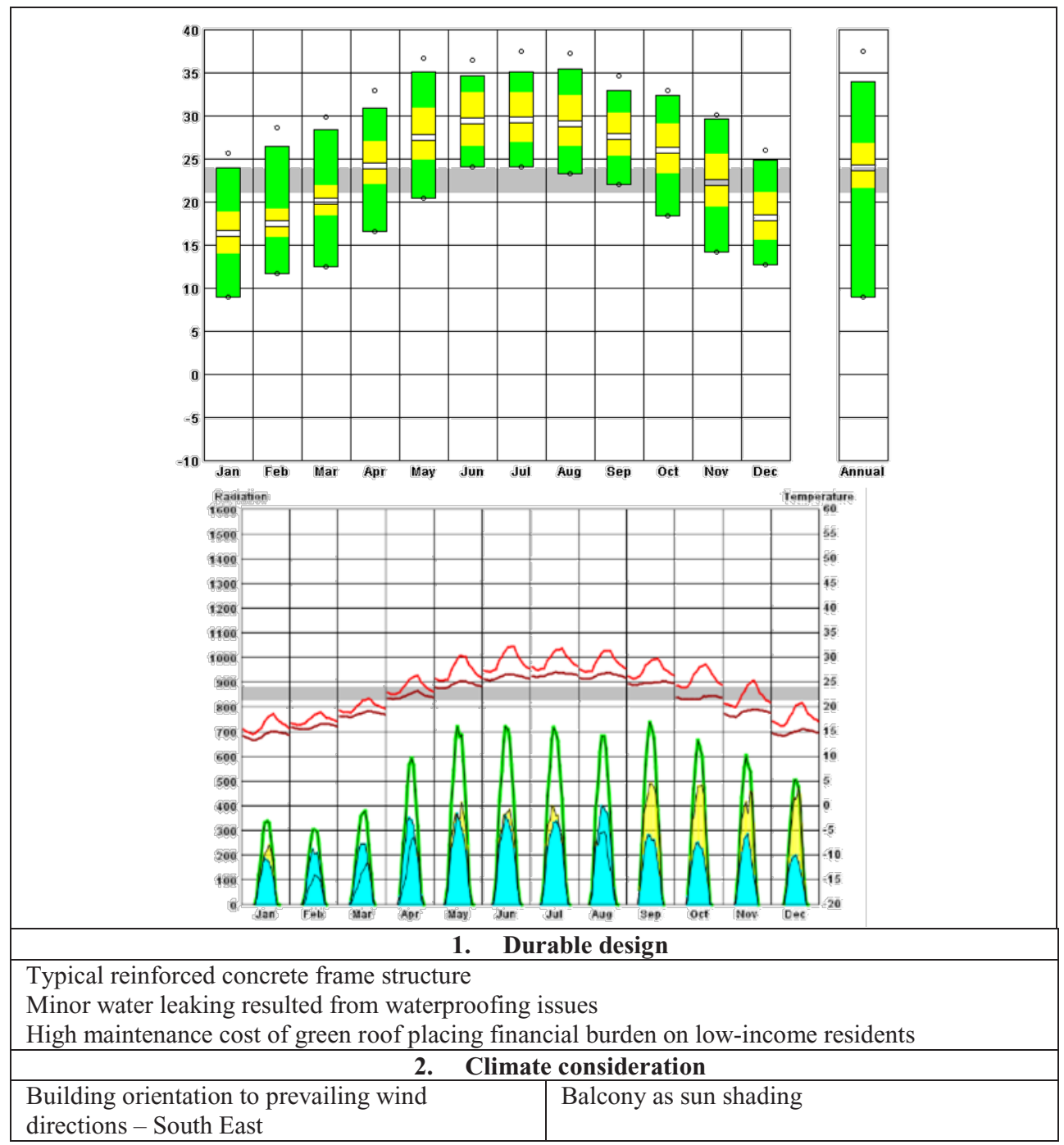



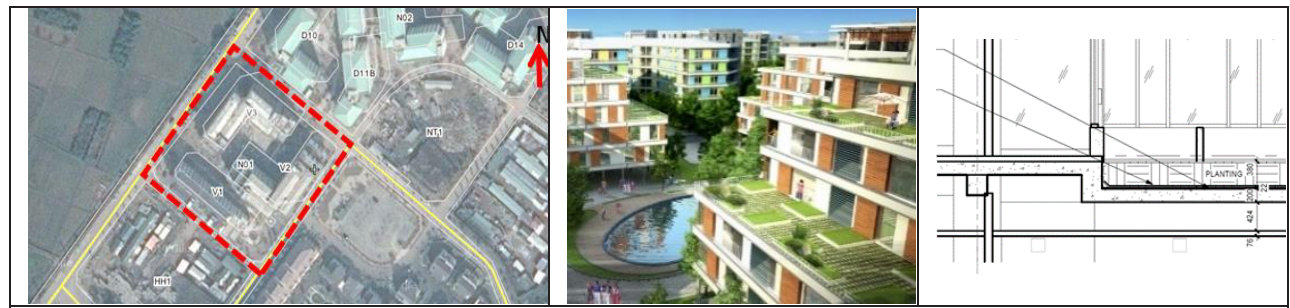

3. Human health considerations

Standing and ceiling fans and standing fans to increase thermal comfort and reduce the use of the air conditioners.
Kitchen area is located close to windows for smell and heat rejection and increase the indoor thermal comfort for residents.
Evaporative cooling: the central courtyards feature with community gardens, kid playgrounds and a swimming pools which also help to cool the temperature of the surroundings.

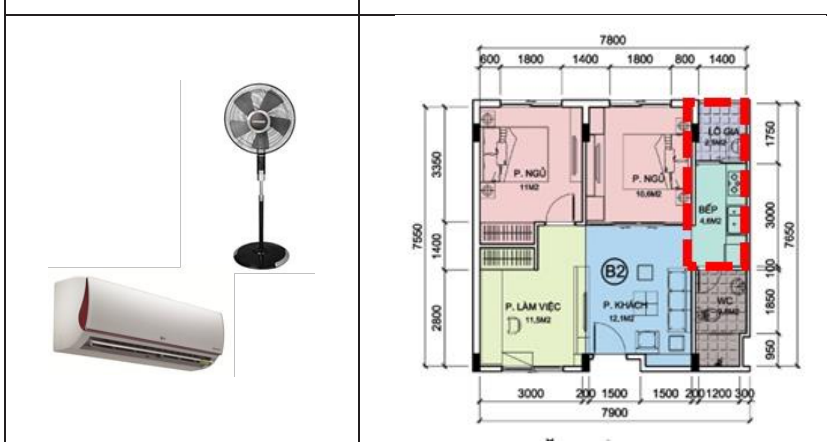

4. Environmental considerations

\begin{tabular}{l|l|l|l|}
$\begin{array}{l}\text { The open first } \\
\text { floor allows for } \\
\text { wind } \\
\text { penetration } \\
\text { into the central } \\
\text { gardens to } \\
\text { enhance } \\
\text { natural } \\
\text { ventilation. }\end{array}$ & $\begin{array}{l}\text { Sufficient } \\
\text { daylighting } \\
\text { penetration from } \\
\text { sided windows. }\end{array}$ & $\begin{array}{l}\text { High energy } \\
\text { efficient light } \\
\text { fixtures such as } \\
\text { LEDs and compact } \\
\text { fluorescent bulbs are } \\
\text { used }\end{array}$ & $\begin{array}{l}\text { Thermal } \\
\text { insulation of roof } \\
\text { assembly }\end{array}$ \\
\hline
\end{tabular}
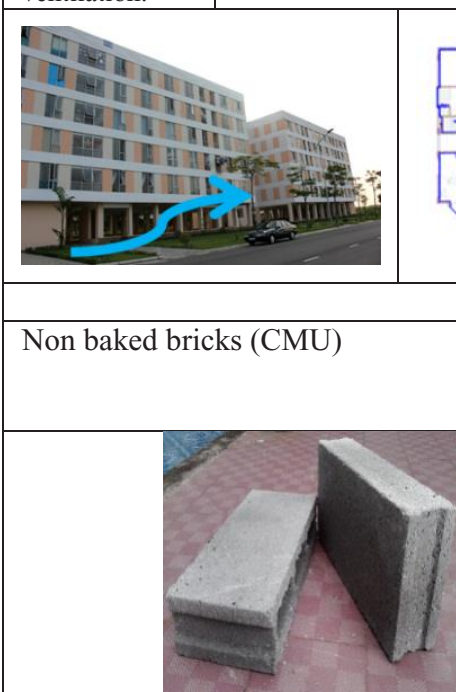

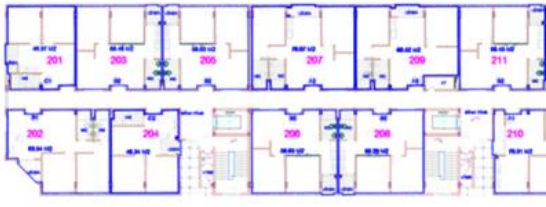

5. Eco-materials
Cross ventilation for units

Local materials and equipment (tiles, bricks, sanitary wares from the local subsidiary of Viglacera Company. 


\subsection{Building B}

- Building description:

The social apartment CT7A at Vinh Diem Trung residential area, Nha Trang city is developed by VinaConex -VCN. The building is located on $8,767 \mathrm{sqm}$.lot. The building is approximate to many public amenities such as supermarket, school, a general hospital, public park, etc. The CT7A is a midrise building with seven stories, featuring with kiosks, retail shops and parking on the first floor.

- Local climate

Nha Trang is a coastal city in the Central South region, having climate characteristics of both tropical climate with the mild and stable oceanic climate conditions. Nha Trang climate has two distinct seasons: wet season and dry season. The average precipitation rate is $1,280 \mathrm{~mm}$ per year and highest raining time is from September to December. The average temperature is $26.4 \mathrm{C}$ and the average humidity level is $79.5 \%$ which is hotter than Hanoi and HCMC.

Table 5. Building B.

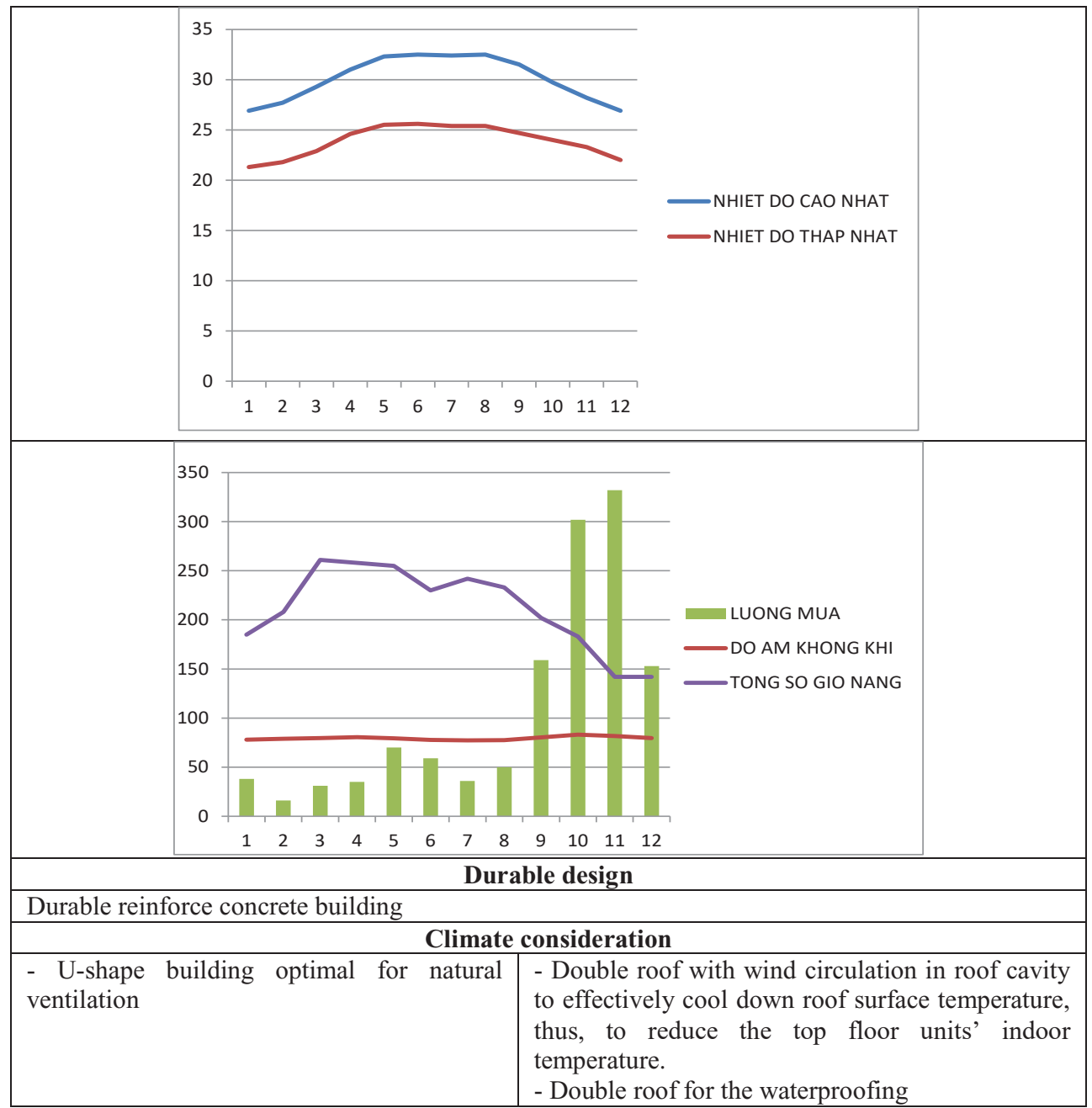




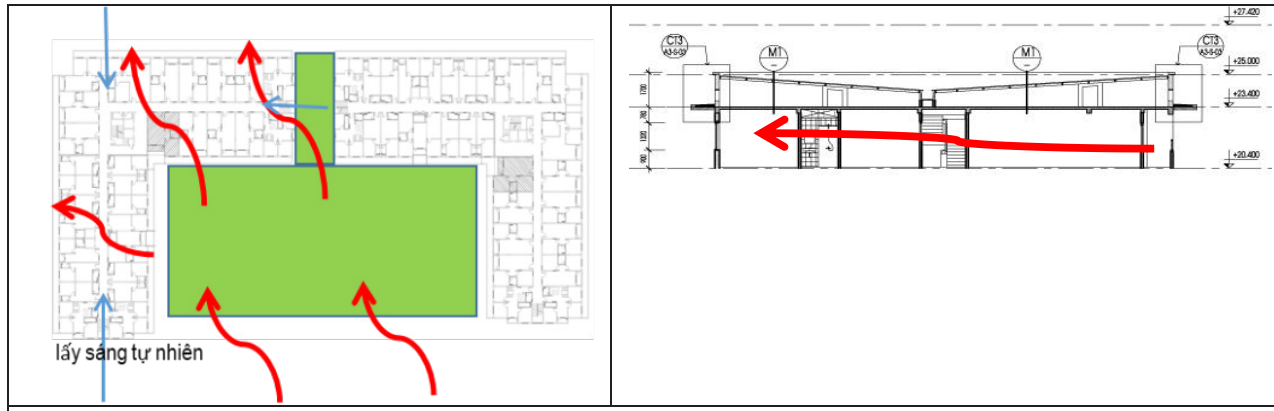

Human health considerations

Louvers and perorated $2^{\text {nd }}$ door for cross ventilation while serving as security
- Ceiling fans and desk fans are used but air conditioners are also installed to maintain occupants' thermal comfort during some period of time when very high temperature and low wind and natural ventilation is not sufficient.

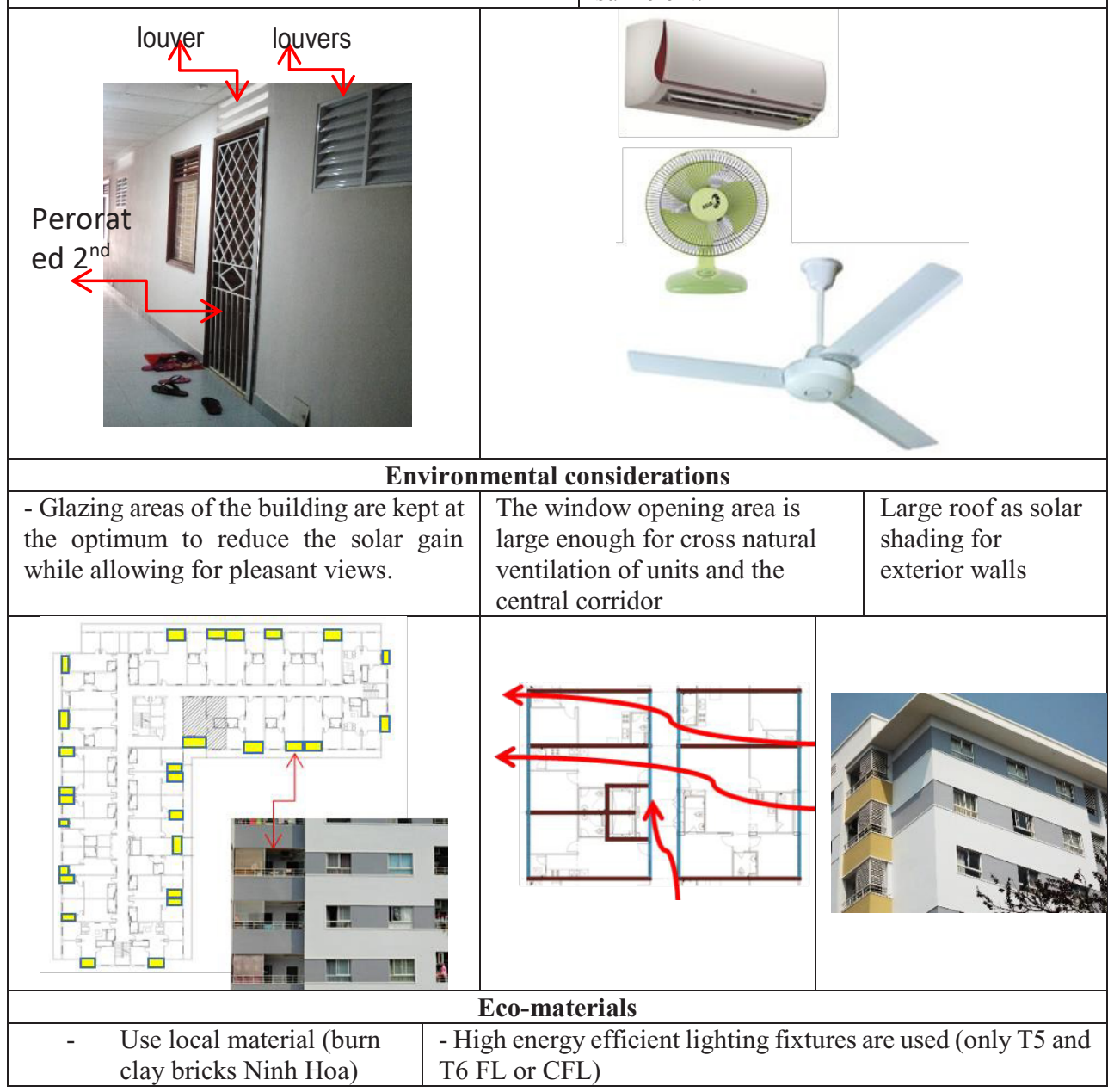




\subsection{Building C}

- Building description:

The Lotus Apartment is located at the central of District 11 Ho Chi Minh City, adjacent to Dam Sen Cultural Park. Withthe coverage area of 1,244.4sqm (built area ratio of 39\%) on the total ground area of $3,082.3 \mathrm{sqm}$., it was completed by 2014 . The 18 -storey building has 255 units, an underground parking as well as a convenient grocery store, a childcare, a community room and a swimming pool on the ground floor.

- Local climate:

HCMC is considered as tropical monsoon climate featuring clearly wet and dry seasons. The wet season is between May-November while dry season is between December and April. Average annual solar radiation is about $140 \mathrm{Kcal} / \mathrm{cm} 2 / \mathrm{yr}$. Sun hour is about 160 270 hour/month. The average temperature is $27^{\circ} \mathrm{C}$. Min temperature is about $25.7^{\circ} \mathrm{C}(\mathrm{Dec}-$ Jan). Max temperature is about $28.8^{\circ} \mathrm{C}$ (April). Annual precipitation is $1,949 \mathrm{~mm}$. Average number of rainy days is about 159 days/year. Average relative humidity is $79.5 \%$. Prevailing winds include seasonal SWS winds from the Indian Ocean and seasonal NNE winds from the East Sea. SSE trade winds occurs between March-May.

Table 6. Building C.

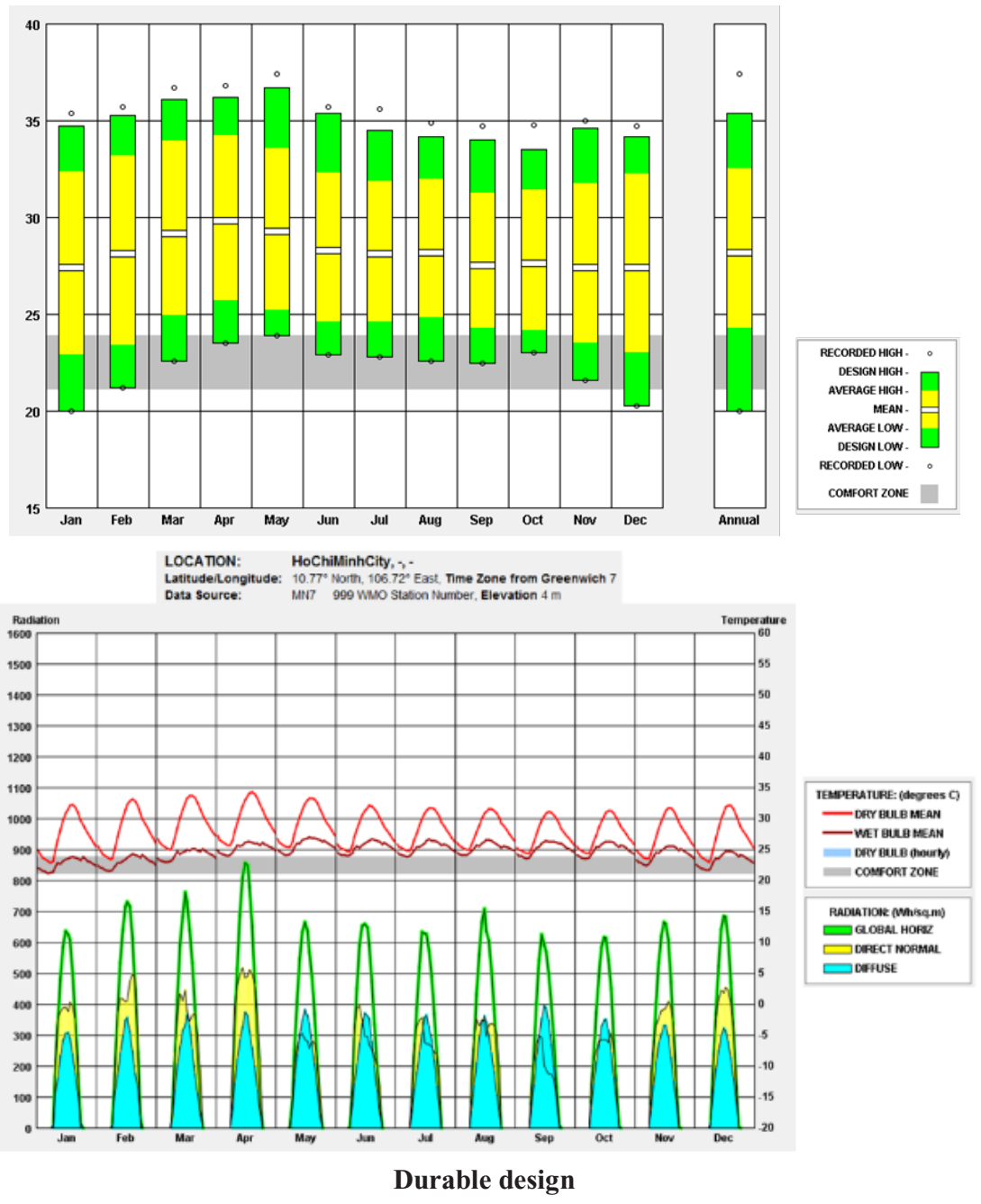


Durable reinforced concrete structure

High quality of exterior coatings with fungi resistance for exterior walls.

\section{Climate consideration}

With a simply rectangular shape and narrow depth, the building's geometry is very suitable for applying natural ventilation. Moreover, the building is oriented in such a way that most of its units are faced to either North or South, minimizing excessive heat gains from the East and the West.

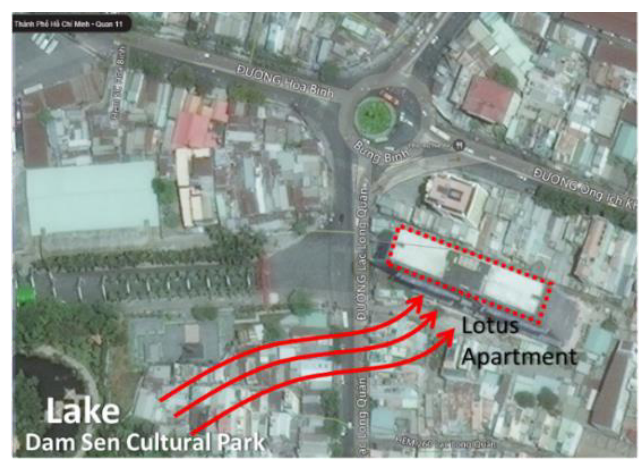

Enjoy cool breezes from the quite big lake of the adjacent Dam Sen Cultural Park which is considered as "the lung" of the region.

\section{Human health considerations}

Loggias for placing washing machines and hanging cloth for drying when needed. The louver screens are also used to block these cloths to avoid unpleasable looks.

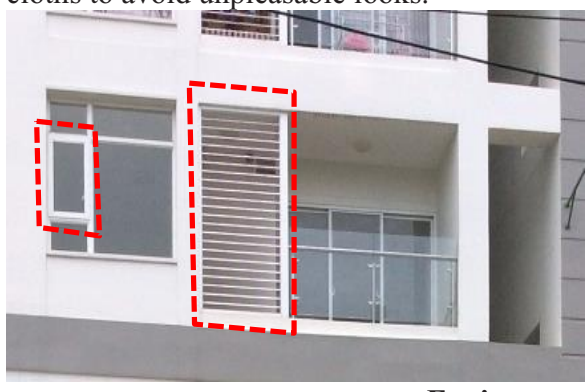

Louver screens as shading devices on loggias Loggias acting as efficient shading devices as well as driving wind into living room

\section{Environmental considerations}

- Light color exterior walls reflecting off sun radiations - Operable windows for natural ventilation - Clear glazing windows maximizing daylighting, thus reducing the needs of using electric lighting
- Narrow rectangular shape is optimal for maximizing daylighting and natural ventilation

- The single central corridor is naturally ventilated however is low daylight. - Light color exterior walls and roof for high solar reflectance.
Energy efficient lighting fixtures such as T8, T5, compact fluorescent or LED lamps were used.

Table fans are widely used by residents for their portable and energy efficient. Split A/C systems are optional and were sometimes installed by residential as a backup for extreme hot days. 


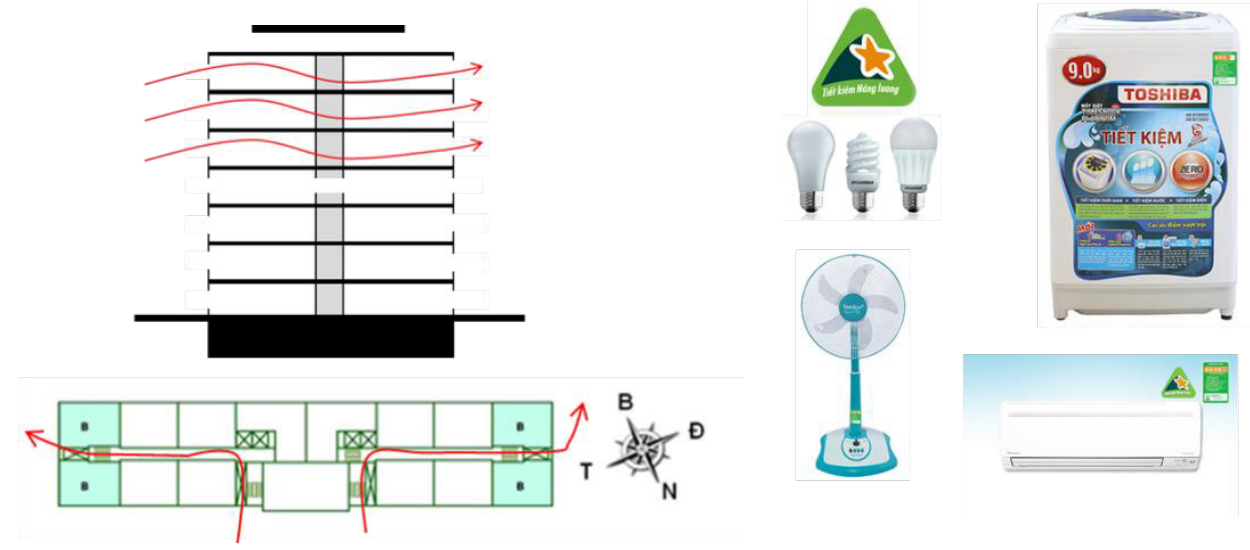

Eco-materials

High thermal resistance AAC blocks to reduce the heat gains through conduction

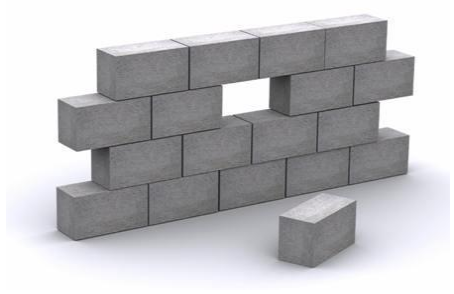

\section{Discussions}

\subsection{Discussions on the ecological design features in three social housing projects}

- Durable design

Most of buildings with traditional reinforced concrete frame are structurally sound. Most problems are water-leaking related issues which disrupt people lives and cause high maintenance and deteriorating the quality of buildings. The double roof from the building B can be seen as a best practice in solving roof water leaking and reducing heat conduction through roofs $[16,17]$.

- Climate considerations

Most buildings show good examples of passive design strategies: optimal building orientations, maximizing local prevailing wind for natural ventilation, utilizing a swimming pool as evaporative cooling technique to improve residents' thermal comfort at the ground levels.

- Human health considerations

Natural ventilation is widely used in all these buildings to enhance thermal comfort and improve indoor air quality. Many buildings still use air conditioners as back-up systems to ensure thermal comfort for unfavorable days. It is should be noted that due to safety regulations in high-rise buildings, the wide clear openings of windows are restricted and insufficient for natural ventilation. Other safety solutions such as louvers or safety screens should be used to increase the size of clear openings for more air flow.

- Environmental considerations

Water efficient fixtures and water closets are widely used as a common practice in most buildings. Incandescent light bulbs are no longer used for its high energy consumption and 
being replaced by T8 or LED light fixtures. Most residents choose electrical appliances that are labeled as energy efficiency for cost savings on electric bills. However, no application of renewable energy such as photovoltaic panels has been applied in any of these buildings [16, 17].

- Eco-materials

Non-baked bricks such as CMU (Concrete masonry unit) and AAC (Autoclaved aerated concrete) are being used to replace traditional fired clay bricks. No reused or recyclable construction materials have being used in the buildings.

\subsection{Discussions on the challenges of eco-social housing development}

- Low awareness of the public in green or ecological social housing

The first challenge is the low public awareness on green or ecological design in social housing projects. There is the lack of confidence on the benefits of green buildings of residents. There is also misleading notion that ecological design will cause cost increase to buildings and thus unfeasible to social housing projects for their limited budget.

- Unfit green building standards for eco-social housing

Although there is an overlap of interests between eco-social housing and green building, it is clear that many guidelines of current green building standards might be inappropriate as they address many issues which are non-critical or irrelevant to conditions of social housing. For example, social housing projects often has higher coverage site ratio than commercial ones, resulting in difficulties in promoting large green areas. Green roofs or other technologies might increase budget and maintenance cost.

Many green building certification systems also cost a certain amount of money for registration, audition and certification. These costs are significant to social housing projects whose budgets are mostly tight. Many of them currently only address to commercial projects and in many cases being used as marketing tools.

- Inadequacy of governmental supports in green or eco-social housing.

At this time, there is strong supports from the government in development of social housing program to low-income people, civil servants, workers, students and other qualified people. However, the level of this support focuses on the quantity of units to meet to the urgent need of providing accommodation for those people. The quality aspects of social housing like ecological considerations have been addressed yet. The lacking of supports from government in eco-social housing can place impacts on the financial burden on these people for low durability, high maintenance cost as well as on the deterioration of natural environment in the long run.

- Lack of related skills, research, and knowledges among stakeholders

Green buildings are not new to many people in Vietnam's building industry and academy environment but the recent practices of green buildings require a high level of up-to-date information, skills and knowledge of the field. Currently, many commercial projects rely on outside services from consultants, resulting in cost increase. To reduce consulting cost, ecosocial housing projects must utilize local human resources: local integrated team with knowledge in local construction practice, local ecological system, eco-social and climate conditions.

\subsection{Discussions on the opportunities of eco-social housing development}

- Job opportunities.

The development of eco-social housing will not only contribute to economic development, bringing jobs to many workers, low-income people but also boosting local economic development through promoting local business, local building materials. 
- Operational cost reduction opportunities.

Eco-social housing improves durability and reduces operation and maintenance cost, thus reducing economic burden on low-income people. For example, an eco-social housing project that comply with the minimum of EDGE criteria (saving 20\% energy, $20 \%$ water and $20 \%$ materials) will elevate the construction cost to $290,000 \mathrm{VND} / \mathrm{sqm}$., but contribute to residents' savings up to $22 \%$ of their utility bills (electricity and water)in comparison to the average estimation from normal social housing projects (Estimation from the authors using EDGE software (www.edgebuildings.com) on the 45 sq.m unit of low-income residential category with building location in HCMC.).

- Available green materials and technologies.

Many green materials and technologies become popular in Vietnam market. For example, the use of non-baked construction materials are widespread to replace baked clay bricks in construction to prevent natural clay depletion, the widespread use of energy efficient lightbulbs (LED) and water efficient fixtures allows for ease of maintenance and cost reduction for utility bills. Significant price drop of photovoltaic panels and recent announce of government in buying back surplus renewable energy are also a positive signal to exploit this energy technology for eco-social housing.

- Green building trend and green policies.

Currently, there is a growing interest of green building in Vietnam construction market. Many green building systems (e.g. LEED, Green Mark, EDGE, LOTUS and so on) adopted in Vietnam have proved their outcomes in cost savings as well as reducing natural resources. The government efforts in this area can be seen as the issuance of and promoting the Energy Efficiency in Building Code (EEBC 09:2013/BXD) focusing on energy efficiency in building design and construction. These green policies are very positive factors for eco-social housing development in the coming years.

\section{Conclusions}

With all opportunities from job creation for low-income people, cost reduction in operation and maintenance to the readiness of green materials and technology as well as availability of green standards and policies, eco-social housing is applicable to Vietnam. Moreover, many ecological design features found in existing social housing projects at certain levels have proved the technical feasibility of eco-social housing.

However, it should be realisticto understand that there still many challenges for the widespread of eco-social housing or ecological design features become indispensable parts in developing social-housing projects in Vietnam.In spite of that challenges, eco-social housing is a solution to Vietnam's needs in providing houses with adequate living conditions to low-income people while protecting the natural environment, ultimately achieving sustainable eco-social development in the long run.

\section{References}

1. Vietnam Affordable Housing - A Way Forward (World Bank Group, 2015)

2. Vietnam Property Market Brief - 2Q16 (JJL Research, 2016)

3. International Energy Outlook 2016 (U.S. Energy Information Administration, 2016)

4. Vietnam Electricity Annual Report 2016 (Vietnam Electricity, 2016)

5. Vietnam: Vulnerability, Risk Reduction, and Adaptation to Climate change (World Bank Group, 2011) 
6. J. Howe, J. Bowyer, K. Fernholz, What's New In Eco-Affordable Housing? Combining Green Building Innovations with Affordable Housing Needs (Dovetail Partners Inc., 2007)

7. The Right to Adequate Housing - Fact Sheet No. 21/Rev.1 (Office of the United Nations High Commissioner for Human Rights, 2009)

8. J. Irwin, Home Insecurity: The State of Social Housing Funding in BC (Canadian Center for Policy Alternatives, 2004)

9. S.T. Pham, Urban Planning Magazine, 18-19 (2014)

10. Ministry of Construction (MOC), Ministry of Construction's work summary in 2016 and task deployment in 2017 (2017)

11. http://www.xaydung.gov.vn/web/guest/trang-chi-tiet/-/tin-chi-tiet/Z2jG/63/343342/boxay-dung-tong-ket-cong-tac-nam-2016-trien-khai-nhiem-vu-ke-hoach-nam-2017.html

12. H. Lan, The 30,000 billion VNDs stimulus package is only disbursed by one tenth (2014)

13. http://kinhdoanh.vnexpress.net/tin-tuc/bat-dong-san/goi-30-000-ty-giai-ngan-duoc-mot -phan-muoi-3078650.html

14. H. Van Hai, N. Phuong Mai, VNU Journal of Economics and Business 29-2, 129-141 (2013)

15. H.-T. Nguyen, M. Gray, Procedia Engineering 142, 314-321 (2016)

16. N. Anh Tuan, Architectural Magazine, 01 (2015)

17. A. Samy, Y. Mohamed, International Journal of Scientific Research \& Engineering Technology (IJSET) 3-2, ISSN: 2356-5608 